Cisneros-Mata, M.A., Delgado, J.A., \& Rodríguez-Félix, D. (2021). Viability of the vaquita, Phocoena sinus (Cetacea: Phocoenidae) population, threatened by poaching of Totoaba macdonaldi (Perciformes: Sciaenidae). Revista de Biología Tropical, 69(2), 588-600. DOI 10.15517/rbt. v69i2.45475

DOI 10.15517/rbt.v69i2.45475

\title{
Viability of the vaquita, Phocoena sinus (Cetacea: Phocoenidae) population, threatened by poaching of Totoaba macdonaldi (Perciformes: Sciaenidae)
}

\author{
Miguel A. Cisneros-Mata ${ }^{1 *}$ \\ Juan A. Delgado ${ }^{2}$ \\ Demetrio Rodríguez-Félix ${ }^{1}$
}

1. Instituto Nacional de Pesca y Acuacultura, Calle 20 No. 605-Sur, CP 85400 Guaymas, Sonora, México; miguel.cisneros@inapesca.gob.mx (*Correspondence),deme771@hotmail.com

2. Tecnológico Nacional de México, km 4 Avenida Tecnológico, Sector Las Playitas, CP 85480 Guaymas, Sonora, México; delgado.juan@uabc.edu.mx

Received 19-I-2021. Corrected 08-IV-2021. Accepted 16-IV-2021.

\begin{abstract}
Introduction: Despite extensive science-based conservation policy recommendations, with fewer than 20 individuals remaining, the vaquita (Phocoena sinus) -endemic to the Gulf of California- is the world's most endangered marine mammal due to incidental catch in fishing nets and whether it can recover is unclear. Objective: Assess expectations for vaquita over the next two decades. Methods: We identified factors affecting the vaquita, constructed life tables, derived demographic parameters for different scenarios and conducted a population viability analysis using stochastic age-structured matrix Leslie models. Results: Analytical results indicate that the vaquita net growth rate is particularly sensitive to juvenile survival. We find that intensive, ongoing bycatch in gillnets used to poach totoaba (Totoaba macdonaldi) over the past decade brought the vaquita population to its current critically low size. Currently this seems to be exacerbated by demographic stochasticity and a potential Allee effect. Conclusions: If totoaba poaching is eliminated immediately, demographically, vaquita can recover; its long-term survival will depend on its uncertain genetic status, although a recent study found encouraging results in this regard.
\end{abstract}

Key words: vaquita; totoaba; demographic stochasticity; Allee effect; population viability analysis.

Vaquita, Phocoena sinus (Norris \& McFarland, 1958), endemic to the Northern Gulf of California (henceforth, UG) is the most endangered marine mammal in the world (RojasBracho, Reeves, \& Jaramillo-Legorreta, 2006; Jaramillo-Legorreta et al., 2019). It is listed as Critically Endangered by the International Union for Conservation of Nature, included in the US Endangered Species Act and in
Mexico's list of endangered species (RojasBracho \& Reeves, 2013).

Major efforts have been made to assess abundance and status of vaquita (Thomas et al., 2017). The population has decreased from $\sim 1000$ individuals 40 years ago (Taylor \& Gerrodette, 1993) to only $400-500$ in the 1990 s (Gerrodette, Barlow, Taylor, \& Silber, 1994). Conservation policies and the expenditure of 
considerable economic resources (US \$ 60 million up to 2017) (Montalvo \& Ortuño, 2017) have not reversed the vaquita decline. Efforts to deter bycatch mortality include buy-out of permits and boats, alternative economic activities, compensations to reduce fishing, and innovations in fishing gear (Avila-Forcada, MartínezCruz, \& Muñoz-Piña, 2012; García-Gómez \& Chávez-Nungaray, 2017). Despite efforts, by 2018 the population dropped to $<20$ (Jaramillo-Legorreta et al., 2019) raising the question of whether vaquita can recover. Encouraging results have been reported recently: mothers have been sighted with calves (Taylor et al., 2019). For descriptions of the historical impact of bycatch from gillnet fishing, particularly poaching of totoaba, the readers are referred to D'Agrosa, Lennert-Cody and Vidal (2000) and the many references in Cisneros-Mata (2020).

To investigate the viability of vaquita we used stochastic Leslie matrix models (SLMMs), conducted a population viability analysis (PVA) (Boyce, 1992; Lamberson, Noon, Voss, \& McKelvey, 1994) and computed probabilities of its persistence through time. SLMMs simulate effects of random survival and birth per age class (Caswell, 1989). Important considerations for PVAs are availability of data and model solutions; analytical solutions and simulations can be combined in some instances (Moloney, Cooper, Ryan, \& Siegfried, 1994; Cisneros-Mata, Botsford, \& Quinn, 1997). Often there is scarce life-cycle information to construct numerical models. Here we use knowledge on vaquita and related species to address relative effects of demographic and anthropogenic factors under several scenarios.

\section{MATERIALS AND METHODS}

Study area: Vaquita inhabits a small portion of the UG off San Felipe, Baja California, around Rocas Consag and of El Golfo de Santa Clara, Sonora at depths of 30 to $>100$ meters (Jaramillo-Legorreta et al., 2019) (Fig. 1; after Rojas-Bracho et al., 2006). Salinity in the Colorado River (CR) delta varies from 38 to
35.4 PSU with prevailing anti-estuary conditions (Lavín \& Sánchez, 1999).

We compiled information from scientific literature and reports on vaquita life history, threats, and abundance. The only proven source of vaquita mortality is incidental take in gillnets and a small proportion in trawl nets (D'Agrosa et al., 2000; Rojas-Bracho et al., 2006; Urrutia-Osorio, Jaramillo-Legorreta, Rojas-Bracho, \& Sosa-Nishizaki, 2015; Flessa et al., 2019). Gillnet mortality from poaching of the endemic sciaenid fish totoaba (Totoaba macdonaldi) has been a major threat to vaquita (Vidal, 1993). The totoaba fishery was banned in 1975, yet constant poaching persisted (Cisneros-Mata, Montemayor-López, \& RománRodríguez, 1995), and has recently (for the past $\sim 10$ years) severely aggravated (Thomas et al., 2017; Cisneros-Mata, 2020).

Decimated populations are subject to low fitness further compromising their existence. For vaquita, inbreeding depression was discarded when its abundance was in the low to mid 100s (Rojas-Bracho \& Taylor, 1999; Rosel \& Rojas-Bracho, 1999; Taylor \& Rojas-Bracho, 1999). Population dynamics at low numbers are governed by demographic stochasticity because survival and fecundity operate at the individual level increasing the risk of extinction by chance survival only (Lee, Seather, \& Engen, 2011). Given its current low population size we consider demographic stochasticity (or chance events) to be critical for the recovery of vaquita.

We further hypothesize the existence of an Allee effect (Dennis, 1989) related to maternal care, characteristic of several mammal species. Mothers nurse and protect their newborns (Hill, Greer, Solangi, \& Kuczaj, 2007) as in P. phocoena in the North Sea (Camphuysen \& Krop, 2011). For this species on the Atlantic coast of the USA, maternal care lasts between 9 and 10 months (Koopman \& Zahorodny, 2008). In our models we assumed that if there is no altruistic conspecific care, a newborn will die if its mother dies, generating a "double death" effect. We caution that this double death may not adjust to the traditional definition of Allee 


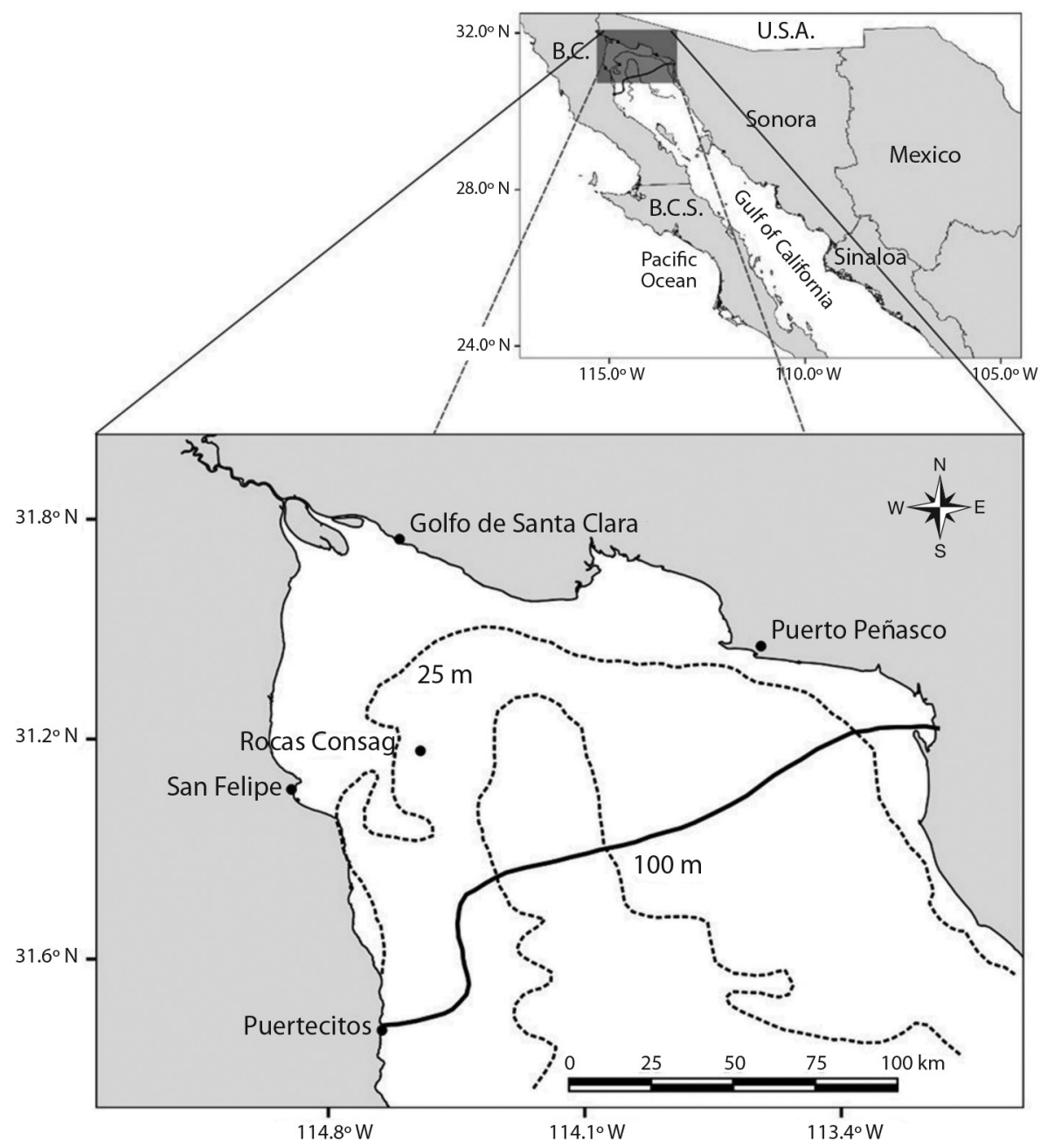

Fig. 1. Distribution range of Phocoena sinus. The continuous line is the Southern limit of sightings, acoustic recordings, and recovery of carcasses and the broken lines depict bathymetric contours.

effects, although we considered as such for reasons discussed below.

We began the analyses by constructing an age-structured life table (Begon, Mortimer, $\&$ Thompson, 1996). In life tables, $1_{x}$ are agespecific survival probabilities from birth to age class $\mathrm{x}\left(\mathrm{l}_{\mathrm{x}}=\mathrm{p}_{0} \mathrm{p}_{1} \mathrm{p}_{2} \ldots \mathrm{p}_{\mathrm{x}-1}\right)$. We used survival rates of $P$. sinus and $P$. phocoena, a related porpoise from the North American coasts (Gaskin, Smith, Watson, Yasui, \& Yurick, 1984; Fenton et al., 2017). The probability of surviving from age class 1 to $2, \mathrm{p}_{0}$, was 0.71 ; this is the square of $\mathrm{p}_{3}=0.84$, as suggested by Barlow (1986). $p_{1}$ and $p_{2}$ were linearly interpolated from those two values $\left(\mathrm{p}_{0}\right.$ and $\left.\mathrm{p}_{3}\right)$; survival rates for age classes 4 to 20 were considered constant $(0.84)$.

Annual parturition rates at-age $\mathrm{x}, \mathrm{m}_{\mathrm{x}}$, were 0.9 for age classes $\geq 6$, while $\mathrm{m}_{4}$ was considered as $1 / 2$ of $\mathrm{m}_{6}$, and $\mathrm{m}_{5}$ was linearly interpolated. In $P$. phocoena annual pregnancy rates vary between 0.91 and 0.24 (Gaskin et al., 1984). The parturition rate for vaquita is 1-2 years (Hohn, Read, Fernández, Vidal, \& Findley, 1996; Taylor et al., 2019).

Sex ratio was arbitrarily considered 1:1 in all cases. For $P$. phocoena a slight bias 
towards males has been observed (Lockyer, 2013; Kesselring, Viquerat, Brehm, \& Siebert, 2017). Vaquita longevity is 21 years, and first reproduction occurs in the fourth year of age (Barlow, 1986; Hohn, et al., 1996).

With this baseline life table, using the Euler-Lotka equation (Birch, 1948):

$$
1=\sum_{1}^{\mathrm{N}} \lambda^{-\mathrm{x}}\left(\mathrm{l}_{\mathrm{x}} \mathrm{m}_{\mathrm{x}}\right)
$$

and the Solver tool in Excel, we derived a vector of "natural" survival rates constrained to yield 643 vaquitas for 1993. This number, considered an initial condition for our models, was back-estimated by eye based on the abundance trend in Jaramillo-Legorreta et al. (2019) who give a mean of 550 vaquitas for 1997, 225 for 2008 and 100 for year 2015 . The net population growth rate $\lambda$ for this baseline table was also estimated from the Euler-Lotka equation.

Reproductive value, $\mathrm{v}_{\mathrm{x}}$, the weighted contribution to population growth by individuals of different ages was computed as (Caswell, 1989):

$$
\mathrm{v}_{1}=1 ; \text { and } \mathrm{v}_{\mathrm{x}}=\frac{\mathrm{m}_{\mathrm{x}}}{\lambda}+\mathrm{p}_{\mathrm{x}}\left(\mathrm{v}_{\mathrm{x}+1}\right) \text { for } \mathrm{x}>1
$$

Note that reproductive value for the first age class will always be 1 . To summarize results, we estimated the average reproductive value for three age groups which we call here juveniles ( 0.5 to 2.5 years), adults (3.5 to 12.5 years) and older adults (13.5 to 21.5 years).

Generation time, the mean age (years) of mothers of a cohort of newborn daughters, was obtained as (Pielou, 1977):

$$
\overline{\mathrm{T}}=\frac{\sum_{1}^{\mathrm{N}} \mathrm{xl}_{\mathrm{x}} \mathrm{m}_{\mathrm{x}}}{\sum_{1}^{\mathrm{N}} \mathrm{l}_{\mathrm{x}} \mathrm{m}_{\mathrm{x}}}
$$

where $\mathrm{N}$ is the total number of age classes. $\overline{\mathrm{T}}$ is used by the International Union for the Conservation of Nature to assess extinction risk of wild populations (Bird et al., 2020).

We used the baseline life table and performed 2000 Monte Carlo trials using a SLMM (Caswell, 1989) to project random annual vaquita abundance trajectories over 38 years starting with a total population of 643 in year 1993. Demographic stochasticity was included considering individual birth and survival rates as Bernoulli trials (Kokko \& Ebenhard, 1996). Population trajectories were generated drawing independent, uncorrelated random numbers to avoid effects in variance (McNamara \& Harding, 2004). This produced a graphical view of how a vaquita population would have grown had by-catch mortality not been present; it also allowed to estimate the net population growth rate $\lambda$ without consideration of Allee effects and bycatch mortality.

We then added Allee effects to the same Leslie matrix to ascertain how this natural process would affect random population trajectories and $\lambda$. We considered that if a female that gave birth died for any reason, her newborn also died that same year. For each trajectory we estimated the net annual rate of increase as $\lambda_{t}=N_{t+1} / N_{t}$ (Nur, 1987) where $N_{t}$ is the total number of vaquitas in a given year $t$; the mean annual growth rate was then computed as the geometric mean over the 38 years, and of the 2000 random trajectories.

To simulate the effect of bycatch mortality, we multiplied age-specific survival rates by a constant factor $(<1)$ for an initial population size of 643 in 1993 constrained to end with 550 vaquitas in 1997. Parturition rates remained constant. This allowed us to determine changes in survival rates and reproductive values, which we attributed to bycatch mortality in fishing nets. This procedure was repeated to fit the mean abundance estimates given also by Jaramillo-Legorreta et al. (2019) for years 2008, 2015, 2016, 2017 and 2018. We note that the latest estimate of abundance is for year 2018 (Dr. Lorenzo Rojas, pers. comm., March 17, 2021).

Monte Carlo simulations were used to determine quasiextinction risk (QR). We recorded the first passage time, i.e., the year when a population trajectory first fell below critical thresholds $(\mathrm{Nc})$; when a trajectory fell below $\mathrm{Nc}$ it was discarded from the original 2000 trajectories. We initiated with a 
population having 13 individuals, approximately corresponding to year 2018 (JaramilloLegorreta et al., 2019). For a given year, QR was estimated as the ratio of first passage time and the number of trajectories remaining that year (Ginzburg, Slobodkin, Johnson, \& Bindman, 1982).

QRs were computed discarding bycatch mortality under three Nc scenarios: 5, 10 and 20 vaquitas in years 2023, 2028, 2033, and 2038. In other words, we computed the probability that the vaquita population will fall below 5,10 and 20 individuals in those four years given that bycatch mortality is $100 \%$ eliminated starting in 2019. Simulations were done in Matlab ${ }^{\circledR}$ version $\mathrm{R} 2018$ b, a platform that can handle matrix algebra appropriately (Miller, Morgan, Ridout, Carey, \& Rothery, 2011).

\section{RESULTS}

When Allee effects are considered, survival rates decrease for the younger age classes, and the highest impact is attributed to bycatch mortality (Fig. 2). It is worth noting the resilience of the vaquita population. In the hypothetical case that bycatch is $100 \%$ eliminated in year 2019 even with a mean number of 13 the model population steadily recovered. This can be more readily appreciated in the inset of Fig. 2.

A steady decrease in age-specific survival was observed in the subsequent periods of 1993-1997 through 2009-2015, followed by a sharp decrease in 2016, increase in 2017 and a final decrease in 2018. Our analysis indicates that the age groups with the lowest survival rates are juveniles ( 0.5 to 3 years), and the oldest (>16.5 years) (Fig. 3 ).

Our analyses indicated that the net population growth rate sharply decreased due to bycatch (Table 1). If no Allee effect is considered, the population would grow $4.4 \%$ per year; when the Allee effect is present the mean net growth rate is $2.6 \%$ per year. When bycatch mortality is considered, the growth rate $\lambda$ reduces to $<1$ meaning that the population is declining. The estimated effect of bycatch plummeted the population for 100 (on average) or less individuals, as indicated by $\lambda<1$. Generation time decreased concomitantly with population size, reproductive value of juveniles and adults, and $\lambda$.

The reproductive value RV also decreased with increasing mortality. Table 1 provides the average reproductive value for three age groups

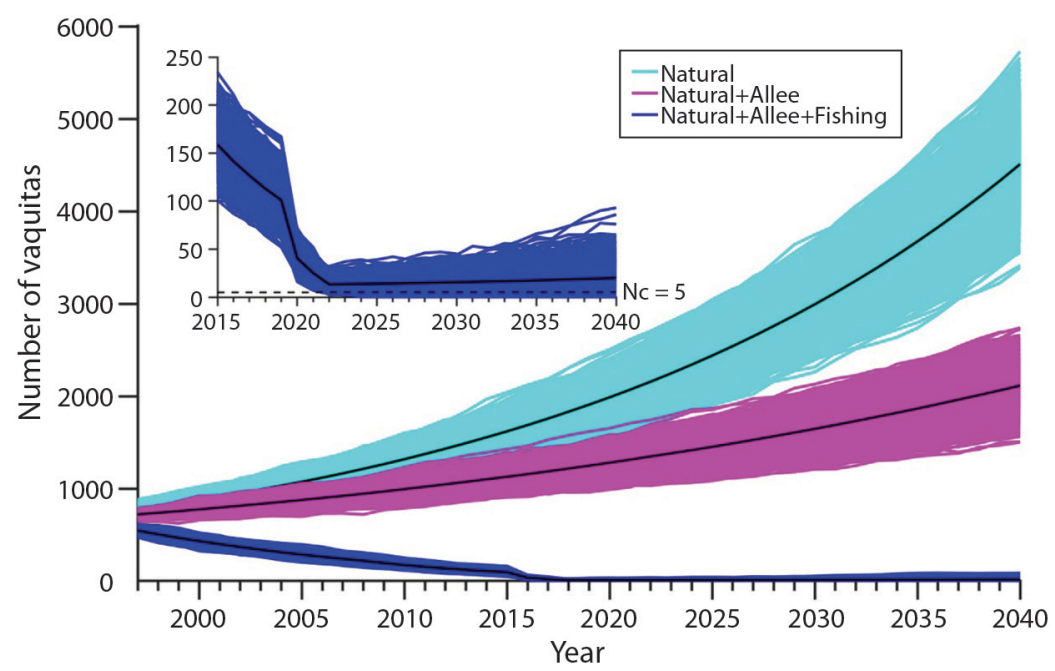

Fig. 2. 2000 random trajectories of the vaquita population considering natural mortality, natural mortality and Allee effects, and natural mortality, Allee effects in addition to bycatch mortality in gillnets. Inset shows a detailed view of the trajectories considering bycatch mortality as well as the $\mathrm{Nc}=5$ critical threshold population size. 


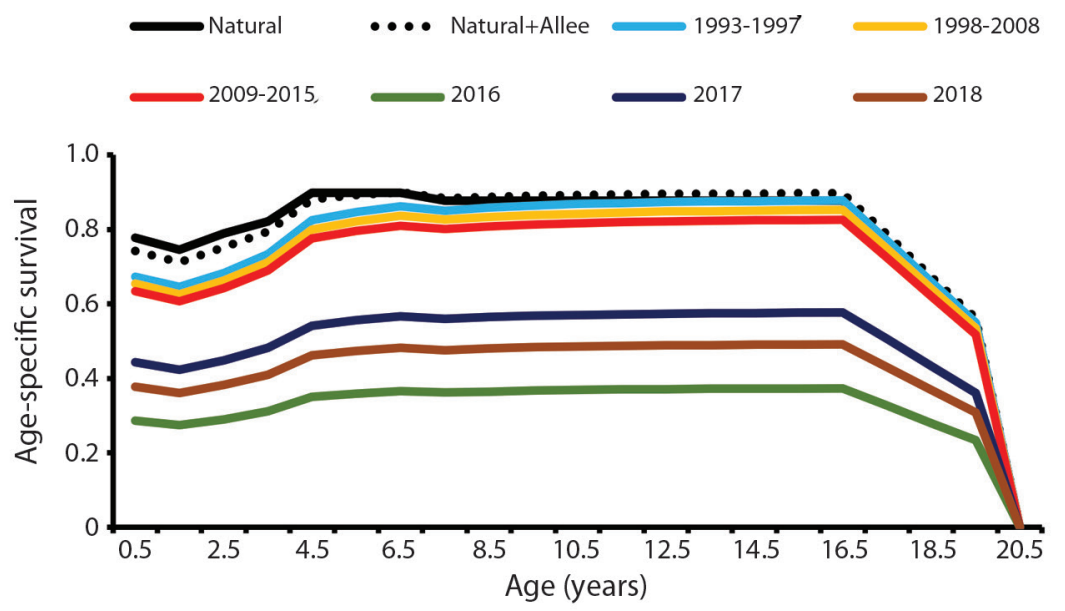

Fig. 3. Annual age-specific survival rates of vaquita under various scenarios. Nat + Allee represents schedules including natural mortality and an Allee effect related to maternal care. The remaining lines represent the survival schedules assuming added bycatch mortality to fit estimated annual abundances in Jaramillo-Legorreta et al. (2019).

TABLE 1

The effect of Allee effect and bycatch on population size $(\mathrm{N})$, net population growth rate $(\lambda)$ and mean reproductive value $(R V)$, and generation time $(\bar{T})$ for three age groups of vaquitas: juveniles (j), adults (a) and older adults (oa)

\begin{tabular}{|c|c|c|c|c|c|c|c|}
\hline Scenario/Parameter & $\mathrm{N}$ (vaquitas) & Year & $\lambda$ & $\mathrm{RVj}$ & $\mathrm{RVa}$ & RVoa & \\
\hline Natural & 643 & 1993 & 1.044 & 1.74 & 3.09 & 1.51 & 9.2 \\
\hline Natural + Allee & 643 & 1993 & 1.026 & 1.66 & 3.31 & 1.60 & 9.4 \\
\hline Natural + Allee + Bycatch & 550 & 1197 & 0.965 & 1.28 & 3.05 & 1.63 & 8.7 \\
\hline Natural + Allee + Bycatch & 225 & 2015 & 0.938 & 1.14 & 2.79 & 1.59 & 8.2 \\
\hline Natural + Allee + Bycatch & 100 & 2015 & 0.910 & 1.02 & 2.57 & 1.56 & 7.7 \\
\hline Natural + Allee + Bycatch & 40 & 2016 & 0.429 & 0.46 & 1.70 & 1.65 & 4.2 \\
\hline Natural + Allee + Bycatch & 25 & 2017 & 0.648 & 0.57 & 1.66 & 1.43 & 5.1 \\
\hline Natural + Allee + Bycatch & 13 & 2018 & 0.557 & 0.51 & 1.61 & 1.48 & 4.7 \\
\hline
\end{tabular}

(juveniles, adults, and older adults). When bycatch mortality is considered, as the number of vaquitas decreased through time the mean RV also decreased almost $75 \%$ for juveniles (1.66 to 0.51 ); for adults, RV decreased almost by half (3.31 to 1.61), and for the older adults, RV reduced only slightly (1.60 to 1.48$)$.

A graphic depiction of reproductive value is given in Fig. 4, which shows how Allee effect and bycatch affects these demographic parameters.

For the three thresholds of vaquitas considered $(5,10,20)$ the probability of quasiextinction (QR) decreases through time because of an upward mean population trend starting in 2022 (Table 2, cf. inset Fig. 2).

\section{DISCUSSION}

In this work we assumed that the relative number of bycaught vaquitas reflect the age structure, decreasing in numbers with age. In a sample of 56 collected carcasses -the majority bycaught in gillnets- most (33) were juveniles followed by older adults (16) and adults (7) (Hohn et al., 1996); no vaquitas were found of ages 3 to 6 or 17 to 20 years. This could be the result of a relatively small 

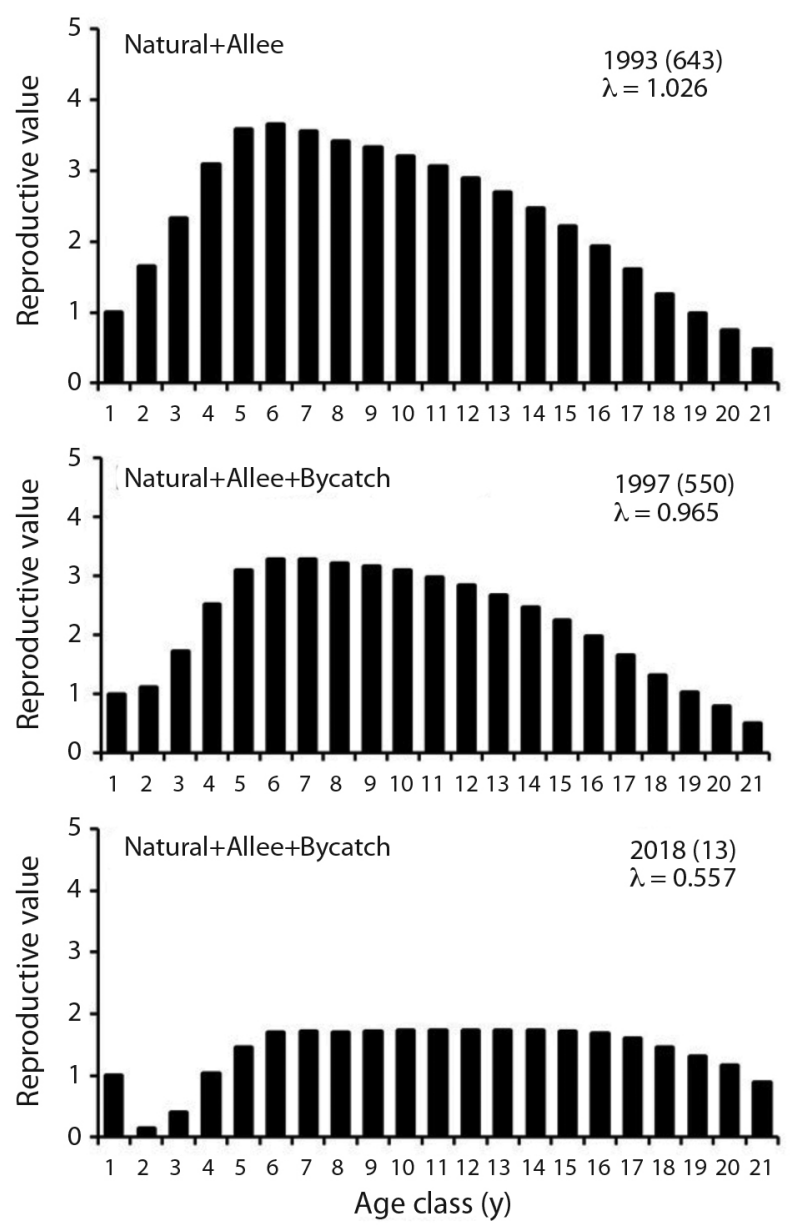

Fig. 4. Age-specific reproductive values for three models of $P$. sinus. Years and abundance (in parentheses) are shown as well as net growth rate $\lambda$. The 643 vaquitas for year 1993 were estimated from data in Jaramillo-Legorreta et al., (2019) and represent the initial condition for our models.

TABLE 2

Quasiextinction risk of a model vaquita population starting with a size of 13 in 2018 and assuming that bycatch mortality is eliminated starting in 2019. Allee effect and demographic stochasticity are considered in 2000 simulations

\begin{tabular}{ccccc} 
Threshold (\# vaquitas) & \multicolumn{4}{c}{ Year } \\
& 2023 & 2028 & 2033 & 2038 \\
5 & 0.0094 & 0.0103 & 0.0056 & 0.0034 \\
10 & 0.0340 & 0.0132 & 0.0061 & 0.0045 \\
20 & 0.0500 & 0.0254 & 0.0094 & 0.0099 \\
\hline
\end{tabular}

sample size or other, unknown factors. Our assumption is based on the facts that 1) fishing effort in the vaquita habitat including poaching of totoaba increased as compared to the 1990s (Rodríguez-Quiroz, Aragón-Noriega,
Valenzuela-Quiñonez, \& Esparza-Leal, 2010), and 2) bycatch of vaquita increased accordingly (Urrutia-Osorio et al., 2015).

Demographic stochasticity acts on individual rates at small population sizes (Lande, 1993; 
Legendre, Clobert, Moller, \& Sorci, 1999). With few conspecifics, Allee effects and demographic stochasticity might further depress growth rate (Courchamp, Clutton-Brock, \& Grenfell, 1999; Berec, Angulo, \& Courchamp, 2007), not evident at high population numbers (Akçakaya, 2000). Allee effects emerge due to decreased cooperation by conspecifics in decimated populations (Lande, 1998); for vaquita we use the term facilitation instead of cooperation (Courchamp et al., 1999) because survival of a female vaquita that just gave birth will increase the likelihood of her calf to survive. We did not find evidence for Phocoeanidae of alloparental altruistic care of newborns by conspecifics (Mann \& Smuts, 1998; Gero, Engelhaupt, Rendell, \& Whitehead, 2009). Therefore, survival of a mother and her newborn represents an important proportional gain in the decimated vaquita population.

An Allee effect is defined as "a positive relationship between any component of individual fitness and either numbers or density of conspecifics" (Stephens, Sutherland, \& Freckleton, 1999). Here we find that this double death effect results in a decline in per capita growth rate as compared to the absence of double death. Per capita growth is defined as $r=\ln (\lambda)$ (Caswell, 1989) and, as shown in Table 1, with a double death effect $\lambda$ (and thus r) decreases. Consequently, this double death effect correlates with fitness, hence our definition as an Allee effect. This is the first work considering the double death effect in vaquita, which has the potential to reduce population growth. Rojas-Bracho et al. (2006) estimated that the maximum vaquita population net growth rate $\lambda$ was lower than 1.04 (or $4 \%$ per year). Our baseline analytical estimate of $\lambda$ for a population without Allee effect is $4.4 \%$ per year, and when an Allee effect is included $\lambda$ decreases to $2.6 \%$ per year. Hohn et al., (1996) found pregnant and lactating juveniles in their sample of gillnetted vaquitas, providing evidence in favor of this demographic process.

When bycatch mortality was included, $\lambda$ decreased to $-3.5 \%$ per year in year 1997 and to $-44.3 \%$ per year in 2018 . Previous works show that fishing decreases the reproductive value (RV) and $\lambda$ in shark populations (Gallucci, Taylor, \& Erzini, 2006). For vaquita bycatch mortality is the "harvested" portion of the population which according to our calculations reduces RV. Further, our results (cf. Table 1) corroborate that in age-structured populations there is a direct relationship between $\lambda, \overline{\mathrm{T}}$ and RV (Schaffer, 1981; Caswell, 1982; O'Grady, Reed, Brook, \& Frankham, 2008).

Despite demographic stochasticity and an Allee effect acting as assumed in the present work, vaquita has the potential to recover from exceedingly small numbers. If bycatch mortality is eliminated in 2019 , the model population recover from only 13 individuals in 2018. This seems to be related to the high sensitivity of $\lambda$ to survival of the youngest age-classes and of adults and thus to the effect of bycatch mortality in RV. For other cetaceans it was found that $\lambda$ is more sensitive to survival of adults than calves (Young \& Keith, 2011). Due to a lagged response because of the age structure, the recovery is not immediate; it takes three years (2019 to 2022) for the population to change from strong negative to a slight positive trend. It is unfortunate that there are no abundance estimates of vaquita for the years 2019 to 2021 to include in the present work. Because of the continued totoaba poaching at least during 2019 (Aceves-Bueno, Read, \& CisnerosMata, 2020), it is likely that the population is smaller now.

Historically, gillnets have produced constant vaquita mortality (Vidal, 1995) which urged the elimination of totoaba poaching. From the late 1980s through the 1990s, 30-40 vaquitas died annually in totoaba gillnets (Silber, 1990; Vidal, 1993), a high rate relative to the population size (Taylor \& Gerrodette, 1993). For a population having between 300 and 500 vaquitas, incidental deaths in totoaba nets were 5-10 \% per year (Villa, 1993). From 1992-2009 bycatch represented $10.78 \%$ of the population and rose to $21.11 \%$ from 20102013 based on numbers in Urrutia-Osorio et al. (2015). This increased bycatch mortality 
coincides with intensified totoaba poaching over the past decade (Cisneros-Mata, 2020).

There have been unsubstantiated arguments for a negative effect on the vaquita population of less Colorado river water into the upper gulf of California (see Flessa et al., 2019). What has not been discarded is the obvious: vaquitas perish in gillnets. Hence, we conclude the same as the vast majority of previous studies: more fishing nets in upper Gulf of California resulted in higher incidental mortality of vaquitas. Moreover, bycatch in totoaba gillnets has an overwhelming negative effect (Morzaria-Luna, Ainsworth, Kaplan, Levin, \& Fulton, 2013).

Variability in mitochondrial DNA is related to effective genetic population size $\mathrm{N}_{\mathrm{e}}$ and vaquita lacks such variability. $\mathrm{N}_{\mathrm{e}}$ is the minimum size below which the genetic makeup is randomly affected in the population (Wright, 1931) and is generally lower than total population size (Cypriano-Souza, da Silva, Engel, \& Bonatto, 2018). Previous work (Taylor \& Rojas-Bracho, 1999) discarded inbreeding depression but concern was raised if the population remained small. $\mathrm{N}_{\mathrm{e}}$ for vaquita could be 1/10 (Frankham, 1995), 1/3 (Nunney, 1993) or $1 / 2$ (Nunney, 1995) of total population. Thus, an investigation of the genetic pool and $\mathrm{N}_{e}$ at the current population size of vaquita is urgently needed.

Extraordinary efforts to assess and save the vaquita have included aerial and boat surveys, passive acoustic techniques, and captive care (Barlow, Fleischer, Forney, \& Maravilla-Chávez, 1993; Taylor \& Gerrodette, 1993; Barlow, Gerrodette, \& Silber, 1997; Jaramillo-Legorreta, Rojas-Bracho, \& Gerrodette, 1999; Jaramillo-Legorreta et al., 2007; Jaramillo-Legorreta et al., 2019; Rojas-Bracho et al., 2019). Despite such efforts, results have been deceptive because no effective actions have been implemented to eliminate bycatch mortality (Bobadilla, Álvarez-Borrego, Avila-Foucat, Lara-Valencia, \& Espejel, 2011; Morzaria-Luna et al., 2013). Moreover, unless poaching of totoaba is completely eliminated it will be futile to implement any form of use for this species, including a catch and release program (see discussion in Cisneros-Mata, 2020). As many studies have previously recommended, serious efforts are needed to eliminate bycatch mortality of vaquita completely and promptly, else it will be impossible to recover this species. Demographically, vaquita seems viable even at extremely low numbers; its genetic makeup will be the factor governing its long-run viability. A recent study (Morin et al., 2020) is encouraging in this respect since it concludes that even with current low numbers the vaquita maintains the genetic diversity of a healthy population.

Ethical statement: authors declare that they all agree with this publication and made significant contributions; that there is no conflict of interest of any kind; and that we followed all pertinent ethical and legal procedures and requirements. All financial sources are fully and clearly stated in the acknowledgements section. A signed document has been filed in the journal archives.

\section{ACKNOWLEDGMENTS}

The authors are indebted to Ere Aceves, Lorenzo Rojas, Alberto Zirino, Tracey Mangin and three anonymous reviewers for comments and criticism to early versions of this work. MACM and DRF thank CONACYT for partial financial support; JAD thanks Tecnológico Nacional de México for granting a leave of absence.

\section{RESUMEN}

Viabilidad de la población de vaquita marina, Phocoena sinus (Cetacea: Phocoenidae), amenazada por la pesca ilegal de Totoaba macdonaldi (Perciformes: Sciaenidae)

Introducción: Pese a las acciones de conservación basadas en la ciencia y las políticas recomendadas, con menos de 20 individuos sobrevivientes, la vaquita (Phocoena sinus) -endémica del Golfo de California- es el mamífero marino más amenazado del mundo debido a su muerte incidental en redes de pesca; una pregunta 
relevante es si su población se puede recuperar. Objetivo: Evaluar las expectativas para la vaquita marina durante los próximos 20 años. Métodos: Identificamos los factores que afectan a la vaquita marina, construimos tablas de vida, derivamos parámetros demográficos para diferentes escenarios y realizamos un análisis de viabilidad poblacional utilizando matrices estocásticas de Leslie, estructuradas por edad. Resultados: La tasa de crecimiento neto de la vaquita es muy sensible a la supervivencia de los juveniles. Encontramos que la captura incidental intensiva y continua en redes de enmalle para la pesca furtiva de totoaba (Totoaba macdonaldi) durante la última década llevó a la población de vaquitas a su actual estado crítico. Esto parece agravarse por la estocasticidad demográfica y un potencial efecto Allee. Conclusiones: Si la pesca furtiva de totoaba se elimina de inmediato, demográficamente la vaquita puede recuperarse; su supervivencia a largo plazo dependerá de su incierto estatus genético, aunque los resultados de un estudio reciente son alentadores en este sentido.

Palabras clave: vaquita; totoaba; estocasticidad demográfica; efecto Allee; análisis de viabilidad poblacional.

\section{REFERENCES}

Aceves-Bueno, E., Read, A.J., \& Cisneros-Mata, M.Á. (2020). Illegal fisheries, environmental crime, and the conservation of marine resources. Conservation Biology, Online ahead of print. DOI: 10.1111/cobi.13674

Akçakaya, H.R. (2000). Population viability analyses with demographically and spatially structured models. Ecological Bulletins, 48, 23-38. DOI: 10.2307/20113246

Avila-Forcada, S., Martínez-Cruz, A.L., \& Muñoz-Piña, C. (2012). Conservation of vaquita marina in the Northern Gulf of California. Marine Policy, 36(3), 613-622. DOI: 10.1016/j.marpol.2011.10.012

Barlow, J. (1986). Factor affecting the recovery of Phocoena sinus, the vaquita or Gulf of California Harbor porpoise. Administrative Report No. LJ 86 37. La Jolla, USA: U.S. National Marine Fisheries Service.

Barlow, J., Fleischer, L., Forney, K.A., \& MaravillaChávez, O. (1993). An experimental aerial survey for the vaquita (Phocoena sinus) in the northern Gulf of California. Marine Mammal Science, 9(1), 89-94.

Barlow, J., Gerrodette, T., \& Silber, G.K. (1997). First estimates of vaquita abundance. Marine Mammal Science, 13(1), 44-58.

Begon, M., Mortimer, M., \& Thompson, D.J. (1996). Population ecology. A unified study of plants and animals (3rd Ed.). Oxford, United Kingdom: Blackwell Science.

Berec, L., Angulo, E., \& Courchamp, F. (2007). Multiple Allee effects and population management. Trends in Ecology \& Evolution, 22(4), 185-191. DOI: $10.1016 /$ j.tree.2006.12.002

Birch, L.C. (1948). The intrinsic rate of natural increase of an insect population. The Journal of Animal Ecology, 17(1), 15-26. DOI: 10.2307/1605

Bird, J.P., Martin, R., Akçakaya, H.R., Gilroy, J., Burfield, I.J., Garnett, S.T., ... Butchart, S.H.M. (2020). Generation lengths of the world's birds and their implications for extinction risk. Conservation Biology, 34(5), 1252-1261. DOI: 10.1111/cobi.13486

Bobadilla, M., Álvarez-Borrego, S., Avila-Foucat, S., LaraValencia, F., \& Espejel, I. (2011). Evolution of environmental policy instruments implemented for the protection of totoaba and the vaquita porpoise in the Upper Gulf of California. Environmental Science \& Policy, 14(8), 998-1007. DOI: 10.1016/j. envsci.2011.06.003

Boyce, M.S. (1992). Population viability analysis. Annual Review of Ecology and Systematics, 23, 481-506.

Camphuysen, K., \& Krop, A. (2011). Maternal care, calftraining and site fidelity in a wild harbour porpoise in the North Sea. Lutra, 54(2), 123-126.

Caswell, H. (1982). Optimal life histories and the maximization of reproductive value: A general theorem for complex life cycles. Ecology, 63(5), 1218-1222. DOI: $10.2307 / 1938846$

Caswell, H. (1989). Matrix population models. Sunderland, USA: Sinauer Associates.

Cisneros-Mata, M.Á., Botsford, L.W., \& Quinn, J.F. (1997). Projecting viability of Totoaba macdonaldi, a population with unknown age-dependent variability. Ecological Applications, 7(3), 968-980.

Cisneros-Mata, M.Á., Montemayor-López, G., \& Román-Rodríguez, M.J. (1995). Life history and conservation of Totoaba macdonaldi. Conservation Biology, 9(4), 806-814. DOI: 10.1046/j.1523-1739.1995.09040806.x

Cisneros-Mata, M.Á. (2020). Evaluación de la población de Totoaba macdonaldi. Mexico City, México: INAPESCA.

Courchamp, F., Clutton-Brock, T., \& Grenfell, B. (1999). Inverse density dependence and the Allee effect. Trends in Ecology and Evolution, 14(10), 405-410. DOI: 10.1016/s0169-5347(99)01683-3

Cypriano-Souza, A.L., da Silva, T.F., Engel, M.H., \& Bonatto, S.L. (2018). Effective population size and the genetic consequences of commercial whaling on the humpback whales (Megaptera novaeangliae) from Southwestern Atlantic Ocean. Genetics and Molecular Biology, 41, 253-262. DOI: 10.1590/1678-4685-gmb-2017-0052 
D’Agrosa, C., Lennert-Cody, C.E., \& Vidal, O. (2000). Vaquita bycatch in Mexico's artisanal gillnet fisheries: driving a small population to extinction. Conservation Biology, 14(4), 1110-1119.

Dennis, B. (1989). Allee effects: population growth, critical density, and the chance of extinction. Natural Resource Modeling, 3(4), 481-538. DOI: 10.1111/j.19397445.1989.tb00119.x

Fenton, H., Daoust, P.Y., Forzán, M.J., Vanderstichel, R.V., Ford, J.K., Spaven, L., ... Raverty, S. (2017). Causes of mortality of harbor porpoises Phocoena phocoena along the Atlantic and Pacific coasts of Canada. Diseases of Aquatic Organisms, 122(3), 171-183. DOI: $10.3354 /$ dao03080

Flessa, K.W., Calderón-Aguilera, L., Cintra-Buenrostro, C.E., Dettman, D.L., Dietl, G.P., Goodwin, D.H., ... Zamora-Arroyo, F. (2019). Vaquita face extinction from bycatch. Comment on Manjarrez-Bringas, N. et al., Lessons for sustainable development: Marine mammal conservation policies and its social and economic effects. Sustainability 2019, 11, 2161-2167. DOI: $10.3390 /$ su11072161

Frankham, R. (1995). Effective population size/adult population size ratios in wildlife: a review. Genetics Research, 66, 95-107.

Gallucci, V.F., Taylor, I.G., \& Erzini, K. (2006). Conservation and management of exploited shark populations based on reproductive value. Canadian Journal of Fisheries and Aquatic Sciences, 63(4), 931-942. DOI: 10.1139/f05-267

García-Gómez, J., \& Chávez-Nungaray, E. (2017). Economic valuation for the socio-environmental protection of the vaquita porpoise, an endemic species. Región y Sociedad, 70, 5-29. DOI: 10.22198/rys.2017.70.a818

Gaskin, D.E., Smith, G.J.D., Watson, A.P., Yasui, W.Y., \& Yurick, D.B. (1984). Reproduction in the porpoises (Phocoenidae): Implications for management. In W. Perrin, R.L. Brownell Jr., \& D.P. DeMaster (Eds.), Reproduction in whales, dolphins and porpoises (pp. 135-148). La Jolla, USA: Proceedings of the conference cetacean reproduction: estimating parameters for stock assessment and management.

Gero, S., Engelhaupt, D., Rendell, L., \& Whitehead, H (2009). Who Cares? Between-group variation in alloparental caregiving in sperm whales. Behavioral Ecology, 20(4), 838-843. DOI: 10.1093/beheco/arp068

Gerrodette, T., Barlow, J., Taylor, B.L., \& Silber, G.K (1994). First population estimates of the endangered porpoise, Phocoena sinus, with implications for monitoring small populations. Jalisco, México: International Meeting of the Society for Conservation Biology and the Association for Tropical Biology.

Ginzburg, L.R., Slobodkin, L.B., Johnson, K., \& Bindman, A.G. (1982). Quasiextinction probabilities as a measure of impact on population growth. Risk Analysis, 2(3), 171-181. DOI: 10.1111/j.1539-6924.1982. tb01379.x

Hill, H.T., Greer, M., Solangi, S.A., \& Kuczaj, I.I. (2007). All mothers are not the same: maternal styles in bottlenose dolphins (Tursiops truncatus). International Journal of Comparative Psychology, 20, 35-54.

Hohn, A.A., Read, A.J., Fernández, S., Vidal, O., \& Findley, L.T. (1996). Life history of the vaquita, Phocoena sinus (Phocoenidae, Cetacea). Journal of Zoology, 239, 235-251. DOI: 10.1111/j.1469-7998.1996. tb05450.x

Jaramillo-Legorreta, A., Cárdenas-Hinojosa, G., Nieto-García, E., Rojas-Bracho, L., Thomas, L., Ver Hoef, J., ... Tregenza, N. (2019). Decline towards extinction of Mexico's vaquita porpoise (Phocoena sinus). Royal Society Open Science, 6, 190598. DOI: 10.1098/rsos.190598

Jaramillo-Legorreta, A., Rojas-Bracho, L., Brownell, R.L., Read, A.J., Reeves, R.R., Ralls, K., \& Taylor, B.L. (2007). Saving the vaquita: immediate action, not more data. Conservation Biology, 21(6), 1653-1655. DOI: $10.1111 / \mathrm{j} .1523-1739.2007 .00825 . x$

Jaramillo-Legorreta, A., Rojas-Bracho, L., \& Gerrodette, T. (1999). A new abundance estimate for vaquita: first step for recovery. Marine Mammal Science, 15, 957-973. DOI: 10.1111/j.1748-7692.1999.tb00872.x

Kesselring, T., Viquerat, S., Brehm, R., \& Siebert, U. (2017). Coming of age: Do female harbour porpoises (Phocoena phocoena) from the North Sea and Baltic Sea have sufficient time to reproduce in a human influenced environment? PLOS ONE, 12(10), e0186951. DOI: 10.1371/journal.pone.0186951

Kokko, H., \& Ebenhard, T. (1996). Measuring the strength of demographic stochasticity. Journal of Theoretical Biology, 183(2), 169-178. DOI: 10.1006/ jtbi.1996.0210

Koopman, H.N., \& Zahorodny, Z.P. (2008). Life history constrains biochemical development in the highly specialized odontocete echolocation system. Proceedings of the Royal Society B: Biological Sciences, 275(1649), 2327-2334. DOI: 10.1098/rspb.2008.0457

Lamberson, R.H., Noon, B.R., Voss, C., \& McKelvey, K.S. (1994). Reserve design for territorial species: the effects of patch size and spacing on the variability of Northern Spotted owl. Conservation Biology, 8(1), 185-195.

Lande, R. (1993). Risks of population extinction from demographic and environmental stochasticity and random catastrophes. The American Naturalist, 142, 911-927. 
Lande, R. (1998). Demographic stochasticity and Allee effect on a scale with isotropic noise. Oikos, 83(2), 353-358. DOI: $10.2307 / 3546849$

Lavín, M.F., \& Sánchez, S. (1999). On how the Colorado River affected the hydrography of the upper Gulf of California. Continental Shelf Research, 19, 15451560. DOI: $10.1016 / \mathrm{S} 0278-4343(99) 00030-8$

Lee, A.M., Seather, B.E., \& Engen, S. (2011). Demographic stochasticity, Allee effects, and extinction: The influence of mating system and sex ratio. The American Naturalist, 177(3), 301-313. DOI: $10.1086 / 658344$

Legendre, S.J., Clobert, J., Moller, A.P., \& Sorci, G. (1999). Demographic stochasticity and social mating system in the process of extinction of small populations: the case of passerines introduced in New Zealand. The American Naturalist, 153(5), 449-453 DOI: $10.1086 / 303195$

Lockyer, C. (2013). Harbour porpoises (Phocoena phocoena) in the North Atlantic: Biological parameters. NAMMCO Scientific Publications, 5, 71-89. DOI: $10.7557 / 3.2740$

Mann, J., \& Smuts, B.B. (1998). Natal attraction: allomaternal care and mother-infant separations in wild bottlenose dolphins. Animal Behaviour, 55(5), $1097-$ 1113. DOI: $10.1006 /$ anbe.1997.0637

McNamara, J.M., \& Harding, K.C. (2004). Measurement error and estimates of population extinction risk. Ecology Letters, 7(1), 16-20. DOI: 10.1046/j.1461-0248.2003.00550.x

Miller, D., Morgan, B.J.T., Ridout, M.S., Carey, P.D., \& Rothery, P. (2011). Methods for exact perturbation analysis. Methods in Ecology and Evolution, 2, 283288. DOI: 10.1111/j.2041-210X.2010.00074.x

Moloney, C.L., Cooper, J., Ryan, P.G., \& Siegfried, W.R (1994). Use of a population model to assess the impact of longline fishing on wandering albatross Diomedea exulanus populations. Biological Conservation, 70, 195-203.

Montalvo, T.L., \& Ortuño, G. (2017). Una inversión de 1,200 mdp no ha servido para rescatar a la vaquita marina. Retrieved from https://www.animalpolitico. com/2017/04/vaquita-marina-inversion-proteccion

Morin, P.A, Archer, F.I., Avila, C.D., Balacco, J.R., Bukhman, Y.V., Chow, W., ... Jarvis, E.D. (2020). Reference genome and demographic history of the most endangered marine mammal, the vaquita. Molecular Ecology Resources, 0, 1-13. DOI: 10.1111/1755-0998.13284

Morzaria-Luna, H.N., Ainsworth, C.H., Kaplan, I.C., Levin, P.S., \& Fulton, E.A. (2013). Indirect effects of conservation policies on the coupled humannatural ecosystem of the upper Gulf of California.
PLoS ONE, 8(5), e64085. DOI: 10.1371/journal. pone. 0064085

Norris, K.S., \& McFarland, W.N. (1958). A new harbour porpoise of the genus Phocoena from the Gulf of California. Journal of Mammalogy, 39, 22-39.

Nunney, L. (1993). The influence of mating system and overlapping generations on effective population size. Evolution, 47(5), 1329-1341. DOI: 10.1111/j.15585646.1993.tb02158.x

Nunney, L. (1995). Measuring the ratio of effective population size to adult numbers using genetic and ecological data. Evolution, 49(2), 389-392. DOI: $10.2307 / 2410351$

Nur, N. (1987). Population growth rate and the measurement of fitness: A critical reflection. Oikos, 48(3), 338-341. DOI: $10.2307 / 3565523$

O’Grady, J.J., Reed, D.H., Brook, B.W., \& Frankham, R. (2008). Extinction risk scales better to generations than to years. Animal Conservation, 11(5), 442-451. DOI: $10.1111 /$ j. 1469-1795.2008.00201.x

Pielou, E.E. (1977). Mathematical Ecology. New York, USA: John Wiley and Sons.

Rodríguez-Quiroz, G., Aragón-Noriega, E.A., ValenzuelaQuiñónez, W., \& Esparza-Leal, H.M. (2010). Artisanal fisheries in the conservation zones of the Upper Gulf of California. Revista de Biología Marina y Oceanografia, 45(1), 89-98.

Rojas-Bracho, L., Gulland, F.M.D., Smith, C.R., Taylor, B., Wells, R.S., Thomas, P. ... Walker, S. (2019). A field effort to capture critically endangered vaquitas Phocoena sinus for protection from entanglement in illegal gillnets. Endangered Species Research, 38, 11-27. DOI: 10.3354/esr00931

Rojas-Bracho, L., Reeves, R.R., \& Jaramillo-Legorreta, A. (2006). Conservation of the vaquita Phocoena sinus. Mammal Review, 36(3), 179-216. DOI: 10.1111/j.1365-2907.2006.00088.x

Rojas-Bracho, L., \& Reeves, R.R. (2013). Vaquitas and gillnets: Mexico's ultimate cetacean conservation challenge. Endangered Species Research, 21, 77-87. DOI: $10.3354 /$ esr00501

Rojas-Bracho, L., \& Taylor, B.L. (1999). Risk factors affecting the vaquita (Phocoena sinus). Marine Mammal Science, 15(4), 974-989. DOI: 10.1111/j.17487692.1999.tb00873.x

Rosel, P.E., \& Rojas-Bracho, L. (1999). Mitochondrial DNA variation in the critically endangered vaquita Phocoena sinus Norris and Macfarland, 1958. Marine Mammal Science, 15(4), 990-1003. DOI: 10.1111/j.1748-7692.1999.tb00874.x 
Schaffer, W.M. (1981). On reproductive value and fitness. Ecology, 62(6), 1683-1685. DOI: 10.2307/1941523

Silber, G.K. (1990). Occurrence and distribution of the vaquita Phocoena sinus in the Northern Gulf of California. United States Fish Bulletin, 88, 339-346.

Stephens, P.A., Sutherland, W.J., \& Freckleton, R.P. (1999). What Is the Allee Effect? Oikos, 87(1), 185190. DOI: $10.2307 / 3547011$

Taylor, B.L., Wells, R.S., Olson, P.A., Brownell, R.L., Gulland, F.M.D., Read, A.J., ... Rojas-Bracho, L. (2019). Likely annual calving in the vaquita, Phocoena sinus: A new hope? Marine Mammal Science, 35(4), 1603-1612. DOI: 10.1111/mms.12595

Taylor, B.L., \& Gerrodette, T. (1993). The uses of statistical power in conservation biology: the vaquita and Northern spotted owl. Conservation Biology, 7(3), 489500. DOI: 10.1046/j.1523-1739.1993.07030489.x

Taylor, B.L., \& Rojas-Bracho, L. (1999). Examining the risk of inbreeding depression in a naturally rare cetacean, the vaquita (Phocoena sinus). Marine Mammal Science, 15(4), 1004-1028. DOI: 10.1111/j.17487692.1999.tb00875.x

Thomas, L., Jaramillo-Legorreta, A., Cárdenas-Hinojosa, G., Nieto-García, E., Rojas-Bracho, L., Ver Hoef, J.M., ... Tregenza, N. (2017). Last call: Passive acoustic monitoring shows continued rapid decline of critically endangered vaquita. The Journal of the Acoustical Society of America, 142(5), EL512-EL517.

Urrutia-Osorio, M.F., Jaramillo-Legorreta, A.M., RojasBracho, L., \& Sosa-Nishizaki, O. (2015). Analysis of the artisanal fisheries of San Felipe, Mexico: Estimating incidental mortality of the vaquita (Phocoena sinus). Journal of Marine Animals and Their Ecology, 8(1), 26-35.

Vidal, O. (1993). Aquatic mammal conservation in Latin America: problems and perspectives. Conservation Biology, 7(4), 788-795.

Vidal, O. (1995). Population biology and incidental mortality of the vaquita, Phocoena sinus. Report of the International Whaling Commission (Special Issue), $16,247-272$.

Villa, B. (1993). Recovery plan for the vaquita, Phocoena sinus. Mexico City, México: Universidad Nacional Autónoma de México.

Wright, S. (1931). Evolution in Mendelian populations. Genetics, 16(3), 97-159.

Young, K.E., \& Keith, E.O. (2011). A comparative analysis of cetacean vital rates using matrix population modeling analysis of cetacean vital rates. International Journal of Applied Science and Technology, 1(6), 261-277. 